\title{
Temporal variability of atmospheric particulate-bound polycyclic aromatic hydrocarbons (PAHs) over central east India: sources and carcinogenic risk assessment
}

\author{
Balram Ambade ${ }^{1} \cdot$ Amit Kumar $^{1} \cdot$ Ashwini Kumar $^{2} \cdot$ Lokesh K. Sahu $^{3}$ \\ Received: 27 April 2021 / Accepted: 2 September 2021 / Published online: 14 September 2021 \\ (c) The Author(s), under exclusive licence to Springer Nature B.V. 2021
}

\begin{abstract}
Atmospheric polycyclic aromatic hydrocarbons (PAHs) are of significant interest owing to their high potential health effects, including mutagenicity and carcinogenicity. We report 16 PAHs measured in ambient $\mathrm{PM}_{2.5}$ from June 2018 to May 2019 over three different sites located in central east India. The annual average $\mathrm{PM}_{2.5}$ mass concentrations of $97.3 \pm 18.1 \mu \mathrm{g} \mathrm{m}^{-3}$, $101.9 \pm 19.4 \mu \mathrm{g} \mathrm{m}^{-3}$, and $93.9 \pm 20.3 \mu \mathrm{g} \mathrm{m}^{-3}$ were measured at RCI (Ranchi), GHY (Gamharia), and BKR (Bokaro), respectively. The mass concentrations at all sampling sites are relatively higher than the annual average concentration of the National Ambient Air Quality Standard. Total annual PAH concentrations ( $\mathrm{ng} \mathrm{m}^{-3}$ ) are found to be comparable at $\operatorname{BKR}\left(797.9 \pm 39.1 \mathrm{ng} \mathrm{m}^{-3}\right)$ and RCI $\left(887.7 \pm 38.8 \mathrm{ng} \mathrm{m}^{-3}\right)$; however, a relatively higher average is observed over GHY $\left(1015.1 \pm 42.7 \mathrm{ng} \mathrm{m}^{-3}\right)$. Using PAH diagnostic ratios and principal component analysis (PCA), their major sources were attributed to coal and wood combustion as well as vehicular emission of diesel and gasoline at all sampling sites. Significant seasonal variability is observed for PAH composition and mainly attributed to change in emission sources. Summer and winter compositions were found to be impacted by the transport from Indo-Gangetic Plains (IGP). However, ambient level PAHs during the post-monsoon season were impacted by mixed sources from Indo-Gangetic Plain and eastern India. These observations are supported by the analysis of back-trajectory and fire count data. The excess life time cancer risk (ELCR) values estimated for the study sites are within acceptable limits suggesting acceptable risk levels at BKR, GHY, and RCI. This study highlights the significance of ambient aerosol concentration for health risks in the pre-COVID-19 scenario.
\end{abstract}

Keywords $\mathrm{PM}_{2.5} \cdot \mathrm{PAHs} \cdot$ Diagnostic ratio $\cdot$ Principal component analysis $\cdot$ ELCR

\section{Introduction}

PAHs are released as a byproduct from the incomplete combustion or pyrolysis of organic matter and fossil fuel and constitute a significant fraction of carbonaceous aerosols. These are a group of ubiquitous aromatic organic pollutants composed of multiple aromatic ring compounds. They can potentially undergo long-range transport, which can

Balram Ambade

bambade.chem@nitjsr.ac.in

1 Department of Chemistry, National Institute of Technology Jamshedpur, Jharkhand 831014, India

2 Geological Oceanography Division, CSIR-National Institute of Oceanography, Dona Paula, Goa 403 004, India

3 Physical Research Laboratory, Space and Atmospheric Sciences Division, Ahmedabad 380009, India subsequently impact at receptor site located remotely from their emission source region (Motelay-massei et al. 2003; Wang et al. 2014a, b; Kaya et al. 2012). Earlier studies have reported that the most common sources of PAHs in the atmosphere are anthropogenic such as industrial emission, coal combustion, wood combustion, heat and power generation or fossil fuel combustion at high temperature, biomass burning, etc. (Galarneau, 2008; Lima et al. 2005; Alves et al. 2015; Harvey, 1997; Miller et al. 2010; Guo et al. 2003). However, few studies also suggest contributions from natural sources such as the forest fires and volcanic eruptions (Liu et al. 2001). These compounds are partitioned in both particulate and gaseous phases and also get formed by secondary processes (heterogeneous reactions of PAHs induced by atmospheric oxidants, viz., $\mathrm{OH}, \mathrm{NO}_{3}, \mathrm{O}_{3}$ ) (Albinet et al. 2007; Atkinson et al. 1989, 1990; Barbas et al. 1996; Environmental Health Criteria (EHC) 229 2003; Helmig and Harger 1994; Sasaki et al. 1997). Higher molecular weight 
PAHs with four and above aromatic rings are condensed to airborne particulate whereas low molecular weight PAHs remain in the gaseous phase (Froehner et al. 2011; Slezakova et al. 2011; Fang et al. 2006; Obiri et al. 2011). Dispersion and subsequent transport of PAHs largely depend on the emission intensity, meteorological conditions (e.g., humidity, wind speed and direction, temperature, precipitation, and solar radiation), and their lifetime in the atmosphere (Baek et al. 1991a; Neilson 2010; Dimashki et al. 2001; Wild and Jones 1995; Vestreng and Klein 2002). In addition, their distributions also depend on the size of particulate matter (Allen et al. 1996), with maximum concentration being found in respirable particulate matter size range less than $3 \mu \mathrm{m}$ (Venkataraman et al. 1994; Baek et al. 1991a,b). Typically, 16 PAH compounds are considered a priority pollutant recognized by the United States Environmental Protection Agency (USEPA 1986).

India, being a developing nation, is under rapid urbanization and industrialization, and a major emitter of carbonaceous species. Recent studies also support this wherein it is found that developing nations in the tropics and southeast Asia are one of the major source regions for the emission of carbonaceous species (Novakov et al. 2003; Streets et al. 2003). While undergoing rapid development, there are possibilities of unplanned energy consumption, which is directly linked to accelerated economic growth. Due to such unplanned practices, the possibilities of PAH emissions are on the higher side as compared to those in developed nations (Kamal et al. 2015; Hafner et al. 2005). In the last few decades, ambient air PAHs have posed a serious environmental concern mainly due to their potential as a health risk, including its carcinogenic and mutagenic properties (Chen et al. 2011; Cerná et al. 1999). Studies have revealed that some of them are highly carcinogenic in laboratory animals and have been implicated in breast, lung, and colon cancers in humans (Yebra-Pimentel et al. 2015). The incremental lifetime cancer risk (ILCR) values for dust containing PAHs indicated a medium to high potential carcinogenic risk for adults and children exposed to it (Shen et al. 2020). Skin contact and ingestion of carcinogenic PAHs from dust are the major exposure pathways and present an exposure risk that is four to five orders of magnitude higher than the risk of inhalation (Shen et al. 2020). It has also been noticed that India, on a global scale, contributes significantly $(\sim 8 \%)$ to the total number of cancer-related issues (Saranath and Khanna, 2014). However, it cannot be exclusively related to PAH emissions. Nevertheless, considering PAH's potential for health risk, it is important to assess their distribution, properties, and emission patterns over the Indian subcontinent on a local to regional scale. In particular, to decouple the impact of recent pandemic COVID-19 on human life, information on PAHs during the pre-COVID period is essential. There have been efforts made to characterize and quantify PAHs at urban (Sharma et al. 2007), semi-urban, rural (Kumar et al. 2020a, b), industrial (Ambade et al. 2021), and relatively pristine regions of the Indian subcontinent. Most of these studies are campaign-based (Chen et al. 2011) and provide a snapshot picture of a particular region. However, there are limited studies on the distribution and characteristics of PAHs on a seasonal basis, showing annual distribution. Such scenarios clearly demand more field-based observations on seasonal to annual scales to assess India's health situation.

In this study, we report the results on the analysis of 16 PAHs measured in $\mathrm{PM}_{2.5}$, collected from June 2018 to May 2019 (pre-COVID-19 period). Our main objectives are (1) to assess temporal variability of PAH concentration over central-eastern India, (2) to apportion the sources of the PAHs using the diagnostic ratios and statistical tools, and (3) to highlight the health risk potential based on the excess life time cancer risk (ELCR) estimates. The present study is important in the context of the deteriorated level of air quality over India, particularly in the Eastern region.

\section{Materials and methods}

\section{Study site and sampling}

$\mathrm{PM}_{2.5}$ samples were collected at three sites, simultaneously, within central-eastern India for 1 year. The geographic locations of sampling sites, namely Gamharia (GHR), Bokaro Steel City (BKR), and Ranchi (RCI), are shown in Fig. 1. GHR is an industrial area situated in Jamshedpur, one of the famous industrial hubs in the state of Jharkhand in centraleastern India. The sampling site in GHR is located near the Adityapur Industrial zone Jamshedpur in the vicinity of several small- to large-scale industries. This particular region is having the status of the special economic zone of India. Along with these industries, there is a highway crossing near the sampling site in GHR. According to the 2011 census, the population of Jamshedpur is around 1.3 million. With a population density of 6400 people per $\mathrm{km}^{2}$, BKR is a semiurban region, one of the well-planned cities in Jharkhand. However, the steel plant sector and middle- to small-scale industries are situated away from the residential areas. The sampling was done at the residential site. The third sampling site is located in Ranchi, capital city of Jharkhand state, with population of $1,439,000$ in 2020 , which is increased by $2.49 \%$ rate from year 2019. (https://www.macrotrends. net). Because of industries and huge traffic emissions, the study of $\mathrm{PM}_{2.5}$ associated with PAHs was carried out. The $\mathrm{RCI}$ site is characterized by the influence of rapid growth of convenient transportation and economic development.

The ambient $\mathrm{PM}_{2.5}$ samples were collected weekly from June 2018 to May 2019 at all sampling sites by following the National Ambient Air Quality standard guidelines (NAAQs 


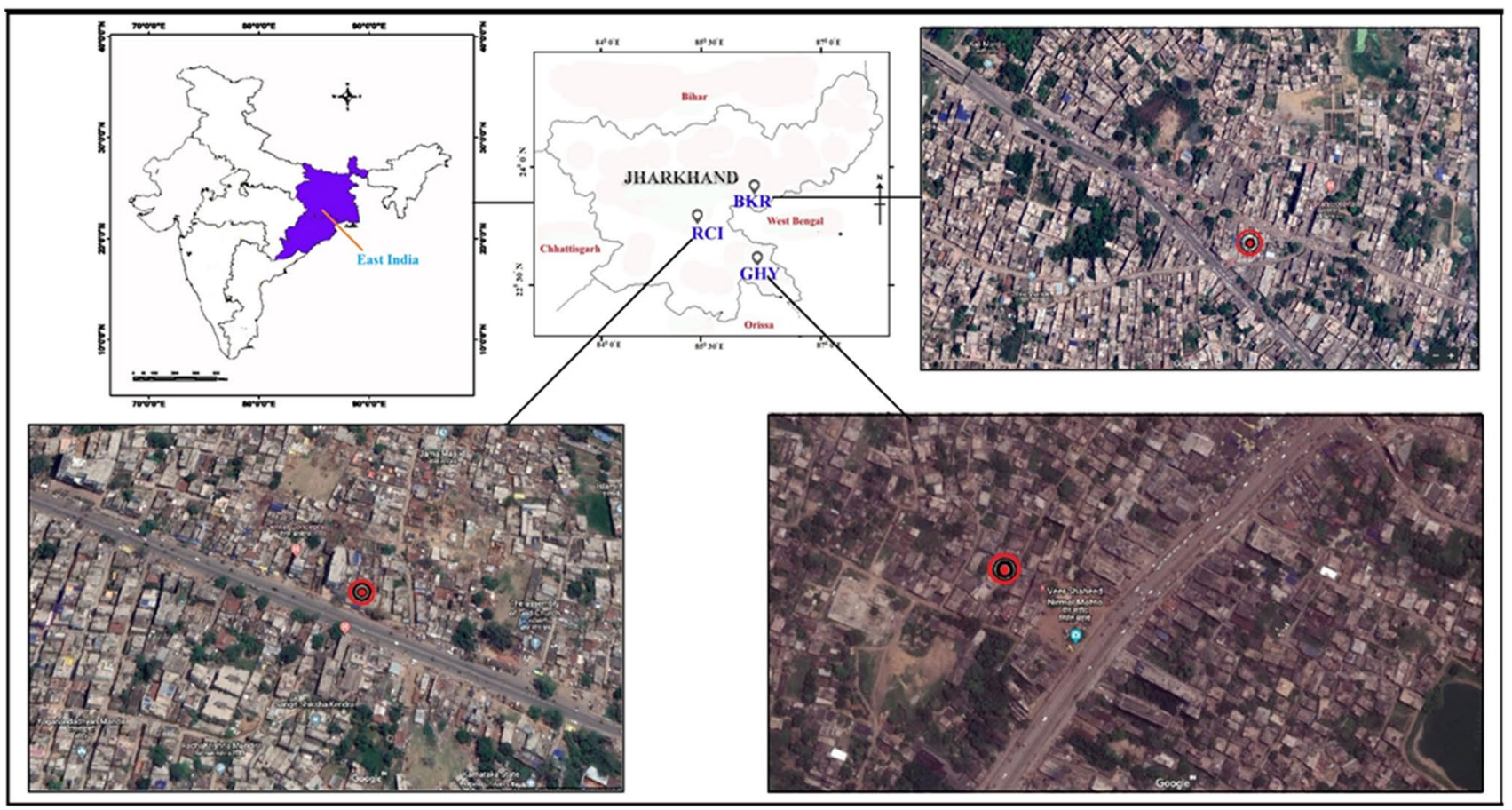

Fig. 1 Locations of the sampling sites in Bokaro (BKR) $\left(23^{\circ} 38^{\prime} 21^{\prime \prime} \mathrm{N}, 86^{\circ} 09^{\prime} 54^{\prime \prime} \mathrm{E}\right)$, Gamharia (GHY) $\left(22^{\circ} 49^{\prime} 04^{\prime \prime} \mathrm{N}, 8^{\circ} 06^{\prime} 01^{\prime \prime} \mathrm{E}\right)$, and Ranchi (RCI) $\left(23^{\circ} 21^{\prime} 45^{\prime \prime} \mathrm{N}, 85^{\circ} 21^{\prime} 01^{\prime \prime} \mathrm{E}\right)$ cities in the east part of India

2009). A total of 140 samples (47 from GHY site, 46 from BKR site, and 47 from RCI site) on weekly basis were collected and analyzed for the PAH concentration. The sampling was carried out using a mini volume sampler (Envirotech Model APM 550), operated at a flow rate of $16.5 \mathrm{l} /$ min. During the campaign, $47 \mathrm{~mm}$ PTFE filter (Merck, Catalog no- PM2547050) was used to collect particulatephase PAHs. The filters were weighed before and after the sampling to determine the weight of the particulate using a single pan-top loading digital analytical balance 4 digit with 0.0001-g sensitivity (VWR, Model no: VWR1611-2263: with weighing chamber $\mathrm{L} \times \mathrm{W} \times \mathrm{H}: 162 \times 171 \times 225 \mathrm{~mm}$ ). Background contamination was checked using operational blanks (unexposed filters), which were processed concurrently with field samples. Furthermore, the filter was kept in a culture box. Until analysis, these samples were kept in the refrigerator at lower temperatures (below $4{ }^{\circ} \mathrm{C}$ ) for preservation. The samples were collected during different seasons which were classified as (1) summer (March to May), (2) winter (December to February), (3) monsoon (June to September), and (4) post-monsoon (October to November). We have used the same classification to discuss the seasonal or temporal variability of particulate and associated PAH concentration in the "Result and discussion" section.

\section{Analysis of PAHs}

Total 16 priority USEPA-PAHs namely naphthalene (NAP), acenaphthylene (Acy), acenaphthene (Ace), fluorene, (Flu), phenanthrene (Phe), anthracene (Ant), fluoranthene (Flua), pyrene (Pyr), chrysene (Chr), benz[ $a]$ anthracene $(\mathrm{BaA})$, benzo[b]fluoranthene $(\mathrm{BbF})$, benzo $[k]$ fluoranthene $(\mathrm{BkF})$, benzo $[a]$ pyrene $(\mathrm{BaP})$, dibenz $[a h]$ anthracene (DBahA), benzo[ghi]perylene $(\mathrm{B}(\mathrm{ghi}) \mathrm{P})$, and indeno[ $123-c d]$ pyrene (IcP) were extracted by soxhlet extraction for $12 \mathrm{~h}$. The full filter was cut into two pieces with care to avoid loss of dust and put into $200 \mathrm{ml}$ distillation vessels for $10 \mathrm{~h}$ using dichloromethane (DCM) solvent. The extraction thimble is initially lowered and shows almost more than $97 \%$ recovery rates. Post-extraction, the extracted volume was reduced up to $10 \mathrm{ml}$ using a rotatory evaporator by maintaining the chiller's temperature for condensing DCM. The solvent is boiling such that the total extraction time is reduced while the evaporated solvent condenses quickly for reuse, dipping the amount of total solvent required. The extract was purified using sodium sulfate-silica gel column (glass column of $30 \mathrm{~cm}$ long and $3 \mathrm{~cm}$ diameter).

Further, purified extracts were reduced to $1-2 \mathrm{ml}$ by a rotatory evaporator and quantified by gas chromatography (GC- FID, Agilent 7890B) coupled with the flame ionization detector (FID) using a capillary column HP- 5MS (30 $\mathrm{m} \times 0.25 \mathrm{~mm}$ i.d $\times 0.25 \mu \mathrm{m})$. In splitless mode, $1 \mu \mathrm{l}$ of 
each sample was injected. Nitrogen was used as carrier gas with a flow rate of $2 \mathrm{ml} \mathrm{min}{ }^{-1}$. The oven temperature was initiated at $60{ }^{\circ} \mathrm{C}$ for $3 \mathrm{~min}$, increased to $320{ }^{\circ} \mathrm{C}$ at rate of $5{ }^{\circ} \mathrm{C} \mathrm{min}^{-1}$, and hold for $20 \mathrm{~min}$. According to the retention factor, the 16 USEPA priority PAHs concentrations were quantified. The laboratory blank and field blank samples were extracted and analyzed in the same way as field sample analysis, and PAH compounds were not detected in blank samples.

\section{Quality assurance}

The 16 PAHs standard solution in acetonitrile (ID-3697900), deuterium leveled PAHs, and hexamethyl benzene (CAS Number-87-85-4) was purchased from Sigma-Aldrich, USA. The chemicals, dichloromethane (CAS Number-75-09-2), anhydrous $\mathrm{Na}_{2} \mathrm{SO}_{4}$ (CAS Number-7757-82-6), sodium chloride (CAS Number-7647-14-5), and silica gel powder (CAS Number-112926-00-8) used in this study, were of AR grade. The procedural blank samples, sample duplicates, and samples spiked with surrogate standards Pyrene- $d_{10}$ (CAS Number -1718-52-1), Anthracene- $d_{10}$ (CAS Number -1719-06-8), Phenanthrene- $d_{10}$ (CAS Number -1517-22-2), Naphthalene- $d_{8}$ (CAS Number -1146-65-2), and Chrysene$d_{12}$ (CAS Number-1719-03-5) were used as the internal standard for the calibration of all species of PAHs and the quality control testing for PAHs analysis relied on these methods. The recovery percentage range of two- or threering PAHs was $60-70 \%$ and more than three-ring PAHs was more than $94 \%$. The standard deviation was $<14 \%$ for this method. The target PAHs' detection limits were calculated three times the standard deviation (SD) plus the mean concentrations of target compounds in blank samples.

\section{Backward trajectories and satellite observed fire count}

In order to investigate the transport from different sources contributing to PAH abundance, we computed 7-day back trajectories. The fire counts retrieved from the Moderate Resolution Imaging Spectroradiometer (MODIS) from the National Aeronautics and Space Administration (NASA) satellite were used to assess active open biomass burning activities over India during the study period. The integrated fire count data are available at https://earthdata.nasa.gov/ earth-observation-data/near-real-time/firms. The 7-day isentropic back trajectory in three dimensions (height, latitude, and longitude) was analyzed for a total run time of $168 \mathrm{~h}$ at a height of $500 \mathrm{~m}$ using the Meteorological Data Explorer (METEX, http://db.cger.nies.go.jp/metex/traje ctory.html). Back trajectory analyses have been conducted at different heights up to $3500 \mathrm{~m}$ above the surface to explain the variability of aerosol properties associated with airborne particulate matter in total atmospheric profile on a seasonal basis.

\section{Health risk assessment}

The toxicity assessment due to exposure of PAHs is calculated for each sample following the toxicity equivalent concentration (TEQ) equation given in Yu et al. (2008) and Yang et al. (2007). The TEQ represents the sum of estimated cancer risk relative to $\mathrm{BaP}$ for all PAHs having carcinogenic potential, which is calculated using the following equation:

$\mathrm{TEQ}=\sum \mathrm{C}_{\mathrm{i}} \times \mathrm{TEF}_{\mathrm{i}}$

where $\mathrm{C}_{\mathrm{i}}$ and $\mathrm{TEF}_{\mathrm{i}}$ are the concentration of individual PAHs and toxicity equivalency factor, respectively. The value of TEF is 1 for $\mathrm{BaP}$ and DBahA; 0.1 for $\mathrm{BaA}, \mathrm{BkF}$, and IcP; and 0.01 for Chr, Ant, and B(ghi)P, Phe, Flt, and Pyr following Nisbet and Lagoy (1992).

The total carcinogenic value can be calculated by TEQ. Furthermore, the exposure risk due to individual PAHs can be quantitatively calculated by incremental lifetime cancer risk (ILCR) (Peng et al. 2011; USEPA., 1991; Chen and Liao., 2006). ILCR was assessed by calculating the corresponding lifetime average daily dose (LADD) of PAHs by considering two age group children (age 6 years) and adults (age 70 years). LADD indicates the amount of chemical suspect intake per $\mathrm{kg}$ of body weight per day and harms health when observed by the body for a long period. The following equations can be used for the estimation of LADD and ILCR.

$\mathrm{LADD}\left(\mathrm{mgkg}^{-1} \mathrm{day}^{-1}\right)=\left(\mathrm{C}_{\mathrm{s}} \times \mathrm{IR} \times \mathrm{CF} \times \mathrm{EF} \times \mathrm{ED}\right) /(\mathrm{BW} \times \mathrm{AT})$

$\mathrm{ILCR}=\mathrm{LADD} \times \mathrm{CSF}($ Cancer Oral Slope Factor $)$

where $\mathrm{Cs}$ is the sum of the converted concentration of PAHs based on TEQ value in airborne particulate $\left(\mathrm{ng} \mathrm{m}^{-3}\right)$. In the present study, the ILCR value was evaluated for child and adult, where parameters were as follows: IR is the air inhalation rate $\left(\mathrm{m}^{3} \mathrm{day}^{-1}\right), \mathrm{CF}$ represents the unit conversion factor $\left(1 \times 10^{-6} \mathrm{mg} \mathrm{kg}^{-1}\right)$, EF represents the exposure frequency (day year ${ }^{-1}$ ), and ED represents the lifetime exposure duration 6 years for children and 52 years for an adult. BW represents the bodyweight $(\mathrm{kg})$, AT represents the averaging time for carcinogens (days), and CSF represents the inhalation cancer slope factor $\left(3.85 \mathrm{mg} \mathrm{kg}^{-1} \mathrm{day}^{-1}\right)$ (Peng et al. 2011). The details of the parameters are described in Table 4. 


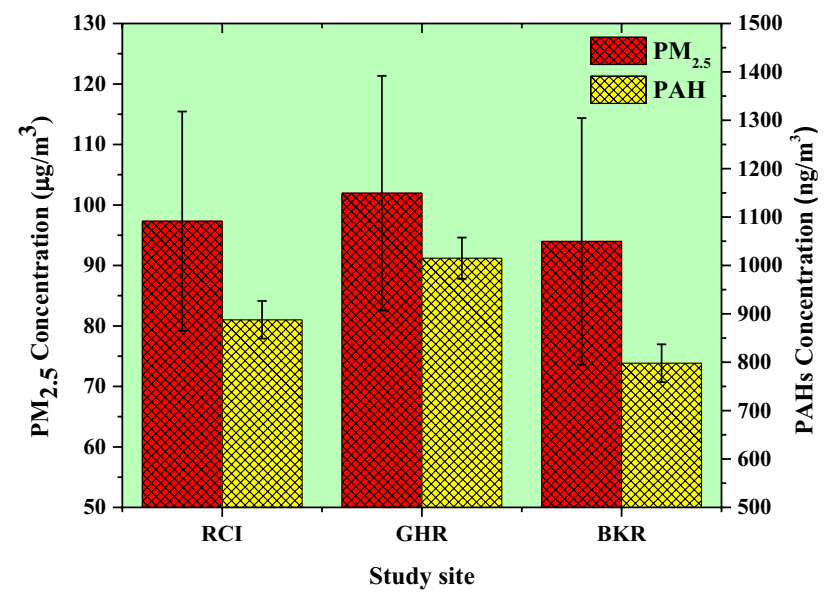

Fig. 2 The annual average concentrations of $\sum \mathrm{PAHs}$ and $\mathrm{PM}_{2.5}$ at three sites (RCI, GHY, and BKR) of central east India

\section{Result and discussion}

The annual average concentrations of $\mathrm{PM}_{2.5}$ were $97.3 \pm 18.1 \mu \mathrm{g} \mathrm{m}^{-3}, 101.9 \pm 1.4 \mu \mathrm{g} \mathrm{m}^{-3}$, and $93.9 \pm 20.3 \mu \mathrm{g} \mathrm{m}^{-3}$ at RCI, GHY, and BKR sites, respectively (Fig. 2). The levels of $\mathrm{PM}_{2.5}$ mass concentrations measured in the present study sites are more than twice higher than the annual average concentration of $40 \mu \mathrm{g} \mathrm{m}^{-3}$ recommended by the National Ambient Air Quality Standard (NAAQ) (NAAQS 2009). This is certainly a matter of concern from the health perspective for those residing in or nearby areas. Although $\mathrm{PM}_{2.5}$ concentrations do not vary significantly between the sites, we found relatively higher $\Sigma$ PAHs (sum of all PAHs) for GHY $\left(1015.1 \pm 42.7 \mathrm{ng} \mathrm{m}^{-3}\right)$ compared to BKR $\left(797.9 \pm 39.1 \mathrm{ng} \mathrm{m}^{-3}\right)$ and RCI $\left(887.7 \pm 38.8 \mathrm{ng} \mathrm{m}^{-3}\right)$. Such higher PAH concentrations may be attributed to relatively more industrial/vehicular emissions from this region as compared to others. The average seasonal concentration of $\mathrm{PM}_{2.5}\left(\mu \mathrm{g} \mathrm{m}^{-3}\right)$ and associated distinct $16 \mathrm{PAH}$ and $\mathrm{PPAH}$ concentration (ng $\mathrm{m}^{-3}$ ) are detailed in Table 1 . The distinctly higher concentrations of both $\mathrm{PM}_{2.5}$ and $\Sigma$ PAHs are observed in winter months followed by summer and post-monsoon seasons with the lowest recorded in the monsoon period (Fig. 3). The higher values in winter months can be attributed to higher contributions from burning of biomass used for heating purpose as well as anthropogenic emission from northern India. During winter months, winds are mostly from north/northeastern direction, which can transport pollutants downwind and can significantly enhance the PAH concentration. BaP is considered a marker of carcinogens, which was found $45.70 \mathrm{ng} \mathrm{m}^{-3}, 47.18 \mathrm{ng} \mathrm{m}^{-3}$, and $43.37 \mathrm{ng} \mathrm{m}^{-3}$ at RCI, GHY, and BKR sites, respectively. Clearly, the concentrations of BaP exceed the NAAQs standard value of $1 \mathrm{ng} \mathrm{m}^{-3}$. Several previous studies have also shown higher values in the winter months compared to other seasons (Singla et al. 2012; Zonguldak Governorship, 2007; Panther et al. 1999; Park et al. 2002; Rajput and Lakhani, 2009). The $\mathrm{PM}_{2.5}$ and $\Sigma \mathrm{PAH}$ concentrations show strong correlations $\left(r^{2}=0.84\right.$ at RCI, $r^{2}=0.82$ at GHY, and $r^{2}=0.79$ at BKR) for all study locations suggesting cogenetic sources of PAHs and $\mathrm{PM}_{2.5}$ (Fig. 4). Typically, high PAH concentrations are associated with small-size airborne particulates due to their large surface area per unit mass, making them good absorbers (Sheu et al. 1997). The concentrations of PAHs in summer season were higher than those during the post-monsoon and monsoon seasons, but lower than the winter months. Except for biomass burning emissions, contributions of other sources such as industrial and vehicular emissions are more or less same for the winter and summer seasons. However, low molecular weight PAHs get converted from particulate to gaseous phase more efficiently at higher temperatures, while photochemical reactions can degrade high molecular weight PAHs. These processes are particularly prevalent during the summer months contributing to PAH loss, and consequently the lower loadings in ambient air. The rain washout of $\mathrm{PM}_{2.5}$ and associated PAHs leads to the lowest concentration during the monsoon season. In comparison to other seasons, the moderate concentrations of $\mathrm{PM}_{2.5}$ and PAHs in the post-monsoon season can be attributed to the moderate emission and meteorological conditions (temperature and precipitation). The highest concentration of PAHs was found in winter because the atmospheric boundary layer (ABL) also plays a very important role in ambient concentrations of PAHs or $\mathrm{PM}_{2.5}$. The ABL depth over a region depends on several factors like incoming solar radiation, topography, and surface roughness of the region as well as other surface forcing, and thus the ABL depth exhibits high spatial and temporal variability. It has been studied that the ABL height is lower in winter and monsoon seasons (Praveena and Kunhikrishnan 2004). However during monsoon, due to the strong prevailing winds, pollutants get dispersed quickly and washed out by frequent precipitation. In contrast to this, both lower winds and shallower ABL depths lead to the highest concentration of hazardous pollutants during winter. Similar impacts of wind and ABL parameters on ambient concentrations of other pollutants, such as volatile organic compounds (VOCs), were reported in several other sites of India (Sahu and Saxena, 2015; Sahu et al. 2016).

\section{Source apportionment of PAHs}

\section{Diagnostic ratio analysis}

In order to reduce emissions of PAHs, it is important to identify the major emission sources and assess their 


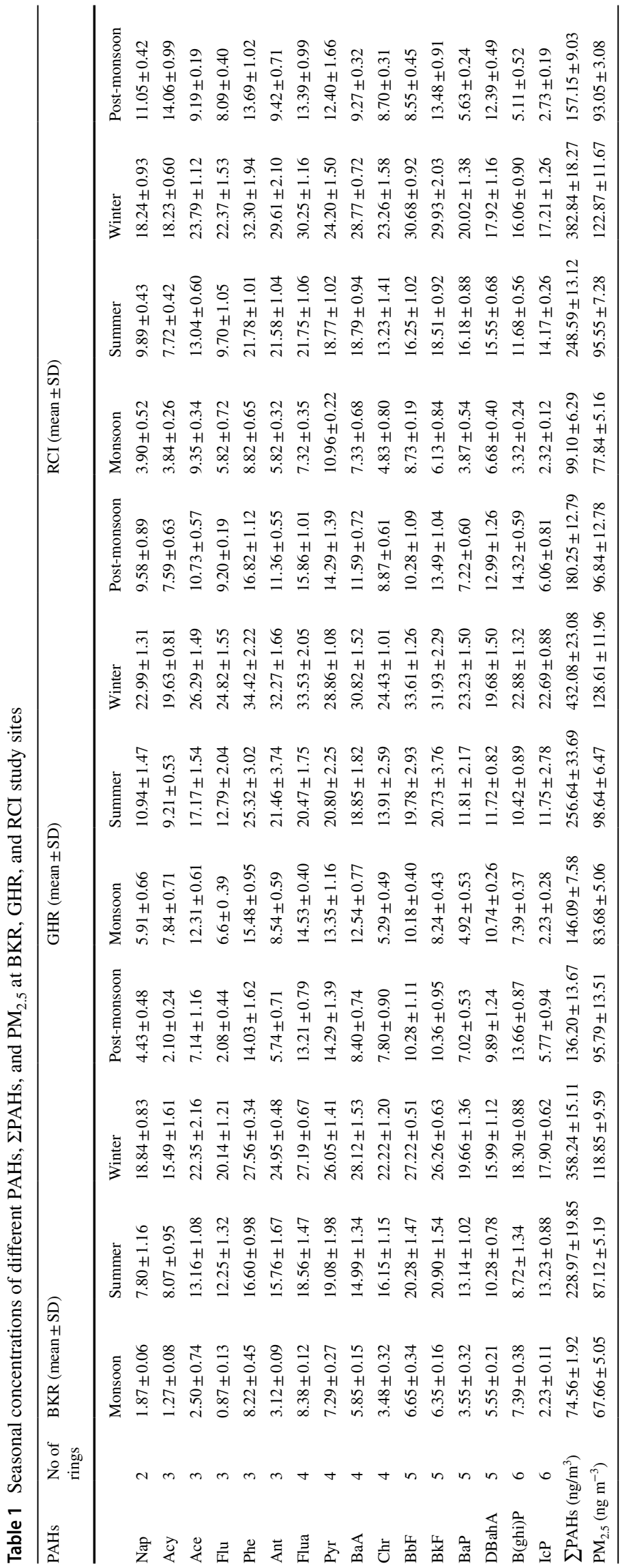



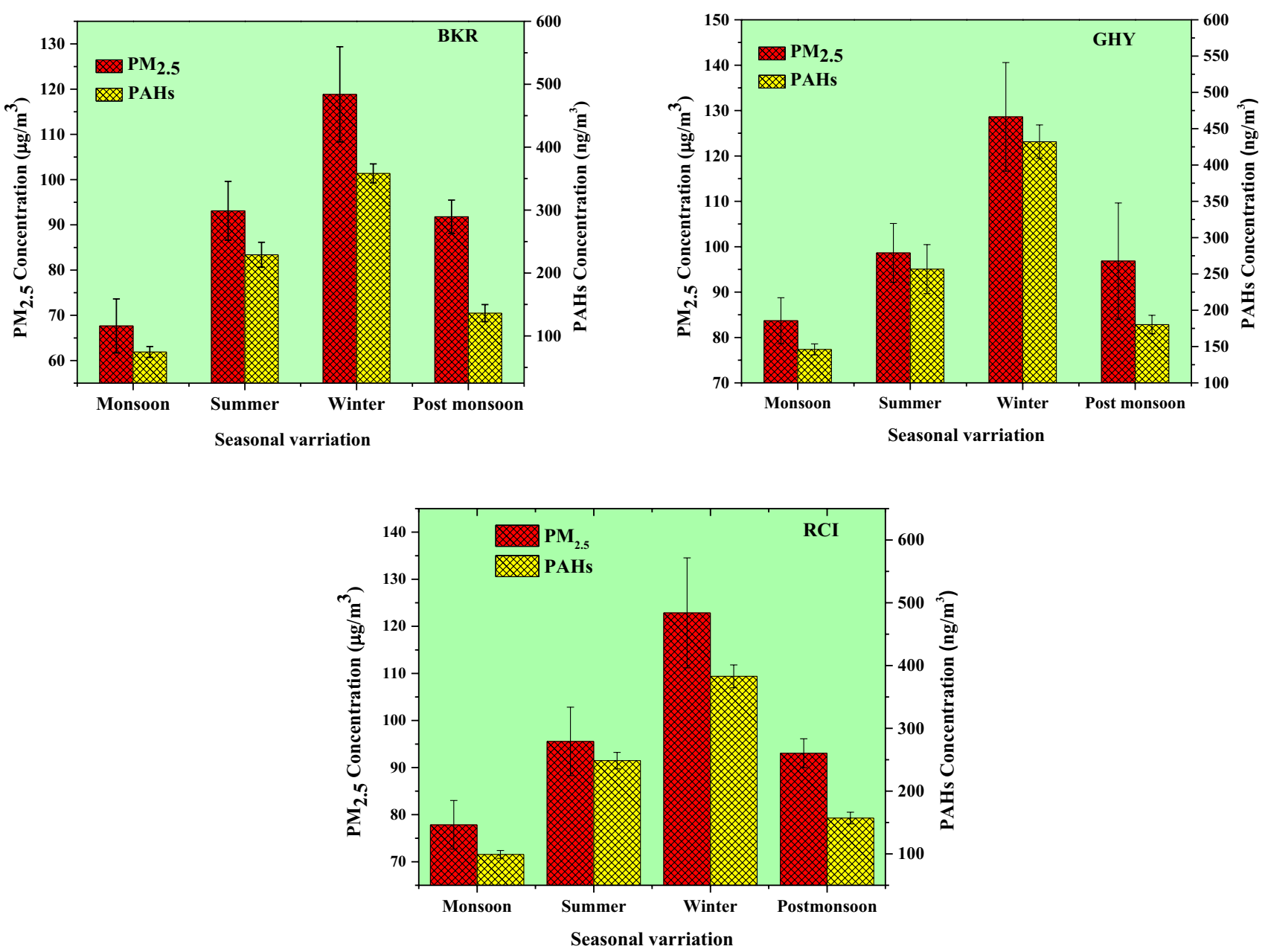

Fig. 3 The seasonal mean concentrations of $\mathrm{PM}_{2.5}$ and $\sum \mathrm{PAHs}$ at three sites (BKR, GHY, and RCI) of central east India

contributions. The diagnostic ratios of particulate-bound PAHs have been extensively used for source apportionment (Tobiszewski and Namieśnik 2012). Typically, the diagnostic ratios of Ant/(Ant + Phe), Flua/(Flua + Pyr), BaA/ $(\mathrm{BaA}+\mathrm{Chr}), \mathrm{IcP} /(\mathrm{IcP}+\mathrm{B}(\mathrm{ghi}) \mathrm{P})$, and $\mathrm{BaP} / \mathrm{B}(\mathrm{ghi}) \mathrm{P}$ are used to separate the contributions of various sources of PAHs in the atmosphere. The Ant/(Ant + Phe) ratio is indicative of pyrogenic and petrogenic sources. The details of emission source are summarized in Table 2, and the scatter plots of their ratios-viz., Ant/(Ant + Phe) versus Flua/(Flua + Pyr), $\mathrm{BaA} /(\mathrm{BaA}+\mathrm{Chr})$ versus $\mathrm{IcP} /(\mathrm{IcP}+\mathrm{B}(\mathrm{ghi}) \mathrm{P})$ and $\mathrm{IcP} /$ $(\mathrm{IcP}+\mathrm{B}($ ghi $) \mathrm{P})$ versus $\mathrm{BaP} / \mathrm{B}(\mathrm{ghi}) \mathrm{P}$ - are depicted in Fig. 5 . These plots also demonstrate their seasonal distribution, and based on their scatter, we will attempt to identify dominant sources of PAHs in different seasons at BKR, GHY, and RCI. Ant/(Ant + Phe) ratio was annually found $0.43,0.44$, and 0.46 over BKR, GHY, and RCI site, respectively. In all seasons, the ratio was found $>0.1$ overall study sites, which means pyrogenic sources were predominant in all seasons at all sites. Flua/(Flua + Pyr) ratio can be used as an indicator of biomass burning, coal combustion, fossil fuel combustion, and unburned petroleum emissions. The ratios $<0.1$ indicate the predominant contribution of unburned petroleum emission, those between 0.4 and 0.5 suggest fossil fuel combustion, and ratios $>0.5$ reflect the biomass and coal combustion (De La Torre-Roche et al. 2009; Yunker et al. 2002). In the present study, the Flua/(Flua + Pyr) ratios of $\sim 0.50,0.52$, and 0.52 were measured at BKR, GHY, and RCI sites, respectively, indicating emission from biomass and coal combustion. However, on a seasonal basis, most ratios for Flua/ (Flua + Pyr) were between 0.4-0.5 and >0.50, which highlight the dominance of fossil fuel combustion and biomass burning sources at the study sites. As reported in several studies, the $\mathrm{BaA} /(\mathrm{BaA}+\mathrm{Chr})$ ratios $<0.2$ indicate petrogenic emission, $0.2-0.35$ indicate petroleum combustion source, and $>0.35$ indicate biomass burning and coal combustion (Yunker et al. 2002; Toblszewski and Namlesnik 2012). In the present study, $\mathrm{BaA} /(\mathrm{BaA}+\mathrm{Chr})$ ratios were $0.46,0.41$, 

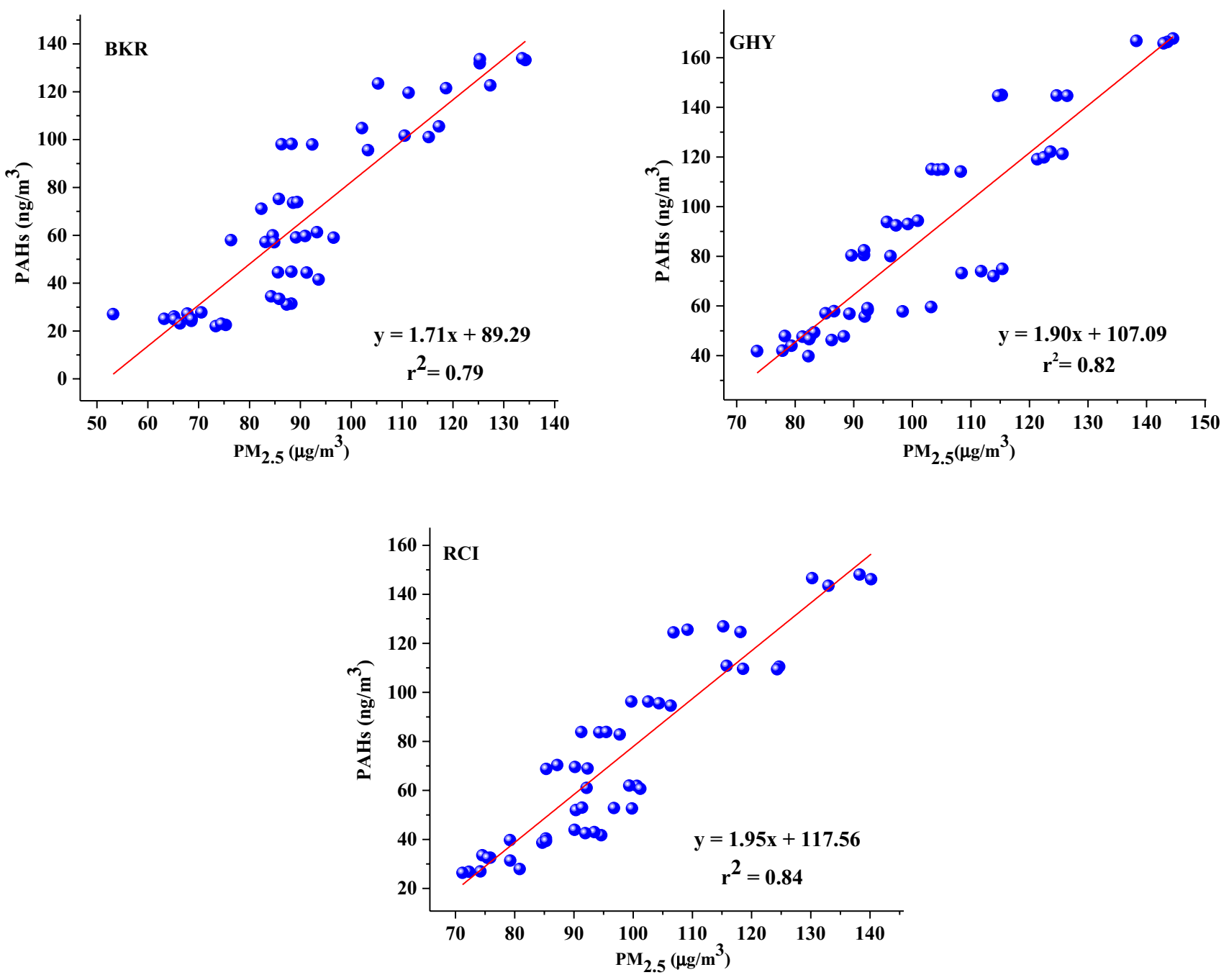

Fig. 4 Correlation analysis between $\mathrm{PM}_{2.5}$ and PAH concentrations at three sites (BKR, GHY, and RCI) of the central east India

and 0.44 at BKR, GHY, and RCI sites, respectively. On a seasonal basis, most of the ratio value lies between $0.2-0.35$ and greater than 0.35 which indicates petroleum combustion and biomass and coal combustion. Kumar et al. (2020a, b) reported that the $\mathrm{BaA} /(\mathrm{BaA}+\mathrm{Chr})$ ratios exceeded 0.2 in all the seasons at both urban and rural areas, indicating that the pyrogenic and coal combustion were predominant sources of emission. The ratio of $\mathrm{BaP} / \mathrm{B}$ (ghi)P can be used to separate the contributions of traffic and non-traffic sources (Hussain et al. 2015). In the present study, the $\mathrm{BaP} / \mathrm{B}$ (ghi)P ratio was more significant than 0.6 in winter and summer all over the study site. Over GHY and BKR, the ratios were $<0.6$ in the monsoon and post-monsoon seasons. Therefore, possibilities of elevation of traffic emission may vary during summer and winter seasons. Overall, based on diagnostic tracers plot, petrogenic, pyrogenic, coal combustion, and vehicular emission were attributed to the primary sources of PAH at the three study sites in different seasons.

\section{Principal component analysis (PCA)}

PCA is a multivariate statistical method widely used for the source identification of particulate-bound PAHs. Three principal components (PCs) were extracted from BKR, GHY, and RCI study sites, accounting for more than $97 \%$ of the total variance. The PAH sources at BKR, GHY, and RCI based on PCs have been described in Table 3. PC-1 shows the variance of more than $92 \%$ of overall study sites and loaded with almost all PAHs. At BKR, PC- 1 shows equal loading of PAHs, but the greatest burden in PC-1 was three, four, and five rings over the entire study site, which indicates the diesel engine emission and coal combustion. Phe, BkF, and $\mathrm{BbF}$ have been used as source markers of diesel engine emissions and Phe, Anth, Chr, Flu, and BaA are frequently used as source indicators for coal combustion (Kong et al. 2012; Fang et al. 2006). PC-2 shows 2.66 and 2.82 variances with high loading of DBahA and B(ghi)P over site BKR and 
Table 2 Spatial and temporal variation of annual mean diagnostic ratio of PAHs

\begin{tabular}{|c|c|c|c|c|c|c|}
\hline Site name & Season & Ant/(Ant + Phe) & Flua/(Flua + Pyr) & $\mathrm{BaA} /(\mathrm{BaA}+\mathrm{Chr})$ & $\mathrm{IcP} /(\mathrm{IcP}+\mathrm{B}(\mathrm{ghi}) \mathrm{P})$ & $\mathrm{BaP} / \mathrm{B}$ (ghi)P \\
\hline \multirow[t]{4}{*}{ BKR } & Winter & $0.4-0.5$ & $0.4-0.6$ & $0.4-0.5$ & $0.4-0.6$ & $0.6-1.8$ \\
\hline & Summer & $0.3-0.6$ & $0.4-0.6$ & $0.4-0.6$ & $0.5-0.8$ & $0.6-2.4$ \\
\hline & Monsoon & $0.1-0.5$ & $0.4-0.6$ & $0.3-0.5$ & $0.1-0.3$ & $0.0-1.8$ \\
\hline & Post-monsoon & $0.2-0.4$ & $0.4-0.6$ & $0.4-0.6$ & $0.1-0.4$ & $0.0-0.8$ \\
\hline \multirow[t]{4}{*}{ GHY } & Winter & $0.4-0.5$ & $0.4-0.6$ & $0.4-0.5$ & $0.4-0.6$ & $0.9-1.2$ \\
\hline & Summer & $0.4-0.6$ & $0.4-0.7$ & $0.4-0.5$ & $0.5-0.7$ & $1.5-1.8$ \\
\hline & Monsoon & $0.2-0.4$ & $0.4-0.7$ & $0.2-0.4$ & $0.1-0.4$ & $0.5-1.5$ \\
\hline & Post-monsoon & $0.4-0.5$ & $0.4-0.6$ & $0.3-0.6$ & $0.2-0.4$ & $0.3-0.7$ \\
\hline \multirow[t]{4}{*}{ RCI } & Winter & $0.4-0.5$ & $0.4-0.5$ & $0.4-0.5$ & $0.3-0.5$ & $1.2-1.5$ \\
\hline & Summer & $0.4-0.5$ & $0.4-0.5$ & $0.3-0.5$ & $0.3-0.5$ & $1.2-1.8$ \\
\hline & Monsoon & $0.3-0.5$ & $0.3-0.5$ & $0.2-0.5$ & $0.2-0.6$ & $0.6-1.8$ \\
\hline & Post-monsoon & $0.3-0.5$ & $0.3-0.5$ & $0.4-0.6$ & $0.4-0.6$ & $0.7-2.0$ \\
\hline Scale & & $\begin{array}{l}<0.1=\text { petrogenic } \\
>0.1=\text { pyrogenic }\end{array}$ & $\begin{array}{l}<0.1=\text { petrogenic/ } \\
\text { unburned petroleum } \\
0.4-0.5=\text { fossil fuel } \\
\text { combustion } \\
>0.5=\text { biomass and } \\
\text { coal combustion }\end{array}$ & $\begin{array}{l}<0.2=\text { petrogenic } \\
0.2-0.35=\text { petroleum } \\
\text { combustion } \\
>0.35=\text { biomass and } \\
\text { coal combustion }\end{array}$ & $\begin{array}{l}<0.2=\text { petrogenic } \\
0.2-0.5=\text { petroleum } \\
\text { combustion } \\
>0.5=\text { biomass and } \\
\text { coal combustion }\end{array}$ & $\begin{array}{l}<0.6=\text { nontraffic } \\
>0.6=\text { traffic }\end{array}$ \\
\hline References & & Pies et al. 2008 & $\begin{array}{l}\text { De La Torre-Roche } \\
\text { et al. (2009), Yunker } \\
\text { et al (2002) }\end{array}$ & $\begin{array}{l}\text { Yunker et al. (2002), } \\
\text { Toblszewski and } \\
\text { Namlesnik (2012) }\end{array}$ & Ravindra et al (2008) & Hussain et al.(2015) \\
\hline
\end{tabular}

GHY respectively and $3.61 \%$ variance over RCI, with high loading of Acy and Nap. B(ghi)P and DBahA and Acy, Nap, Pyr, Ace, BaP, and Flu which were known as a source marker of the gasoline engine and biomass combustion (Zhang et al. 2005; Wang et al. 2011) and low loading of Nap and Flu were indicators as components of low-temperature pyrolytic
Fig. 5 Diagnostic ratios of PAHs in different seasons at three sites (BKR, GHY, and $\mathrm{RCI})$ of the central east India
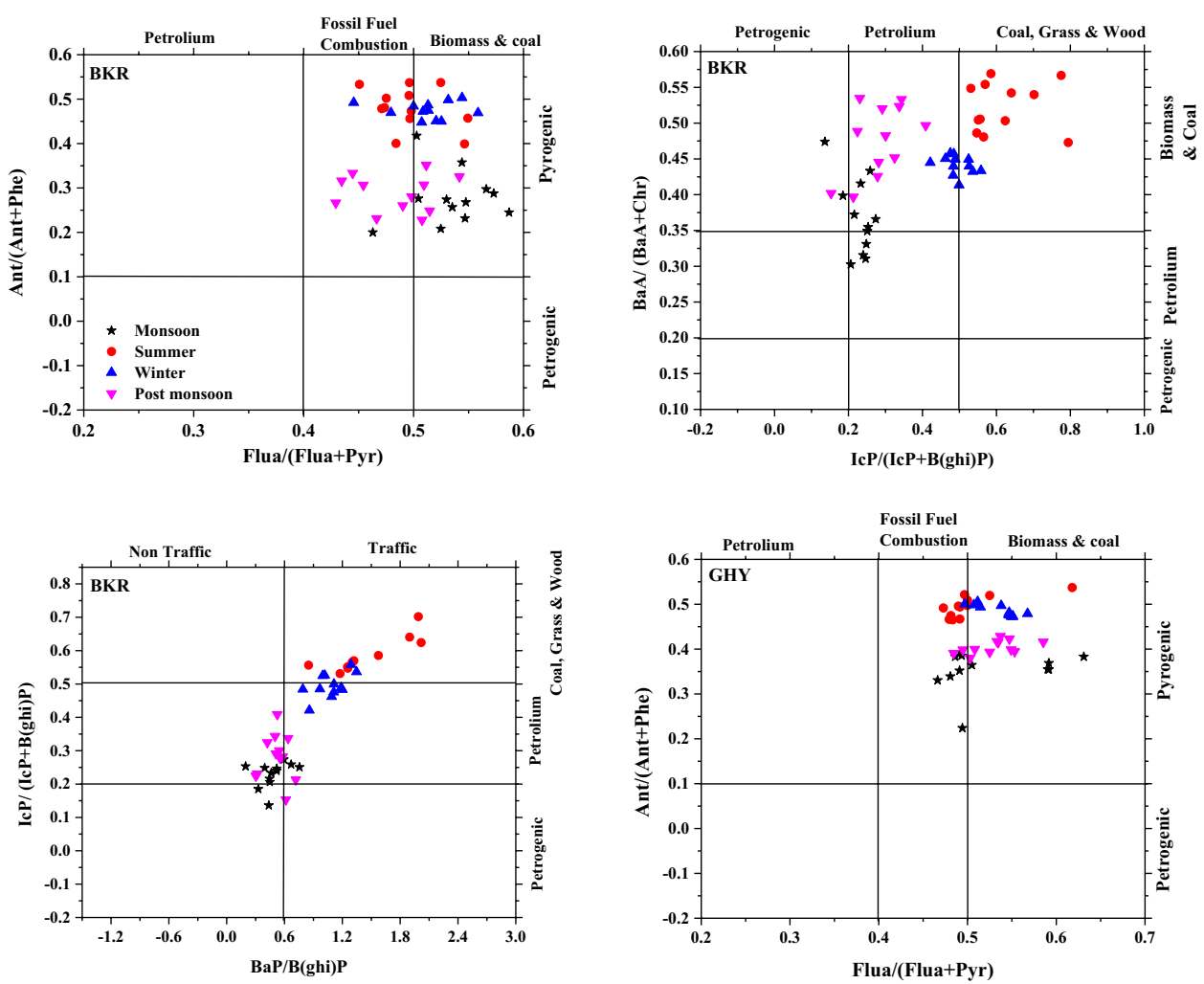
Fig. 5 (continued)
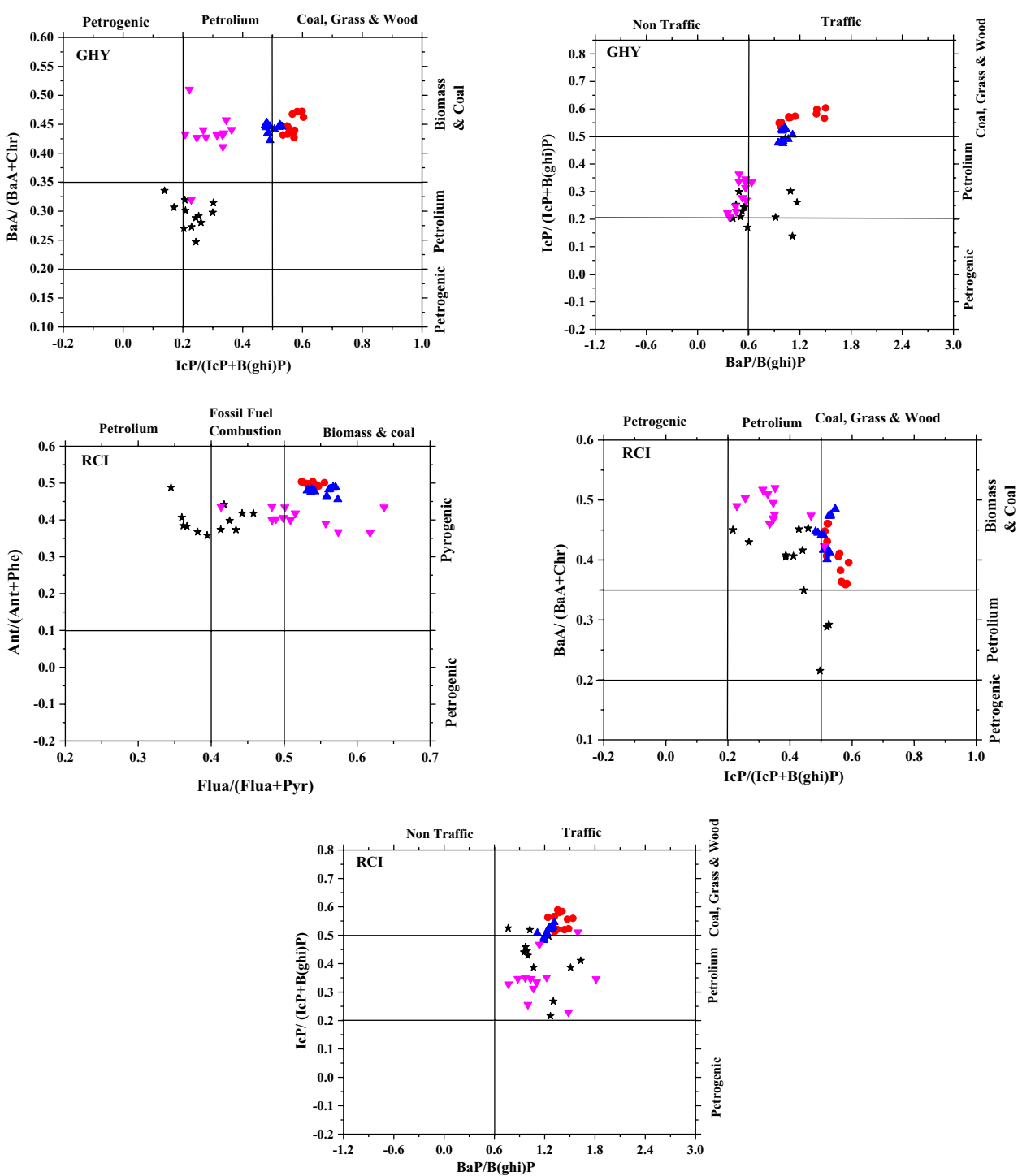

sources (Luo et al. 2006). PC-3 shows 2.34, 1.13, and 1.67\% variance over BKR, GHY, and RCI respectively. PC-3 of BKR site shows high loading of Acy, Flu, and BaA and over GHY high loading of Acy, Ace, and BaA. Acy and Ace is the source fingerprint of pyrosynthesis of oil fumes (Larsen and Baker., 2003). PC-3 of site RCI shows high loading of DBahA indicator of gasoline engine combustion. $\mathrm{B}$ (ghi) $\mathrm{P}$ and DBahA are known as source fingerprints of gasoline engines (Zhang et al. 2005; Wang et al. 2011). Hence, the result of PCA revealed a mixed source of emission of PAHs. The major source of PAHs over the BKR, GHY, and RCI was found to be coal and wood combustion (biomass burning) as well as vehicular emission using diesel and gasoline. This observation is consistent with those observed using the diagnostic tracer method in the previous section. The analysis of the diagnostic ratio and PCA concluded that the major source of $\mathrm{PM}_{2.5}$-associated PAHs was petrogenic, pyrogenic, coal combustion, and vehicular emission which were predominant sources of emission of PAHs.

\section{Impact of long-range transport and biomass burning}

Back trajectory analyses have been conducted at different heights up to $500 \mathrm{~m}$ above the surface to explain the variability of aerosol properties associated with airborne particulate matter in total atmospheric profile on a seasonal basis (Fig. 6). In monsoon season, the trajectories suggest the transport from the remote southwestern part of India as well as Arabian Peninsula. However, mixed patterns were observed during the post-monsoon season as origins of trajectories can be tracked over the IGP and over eastern India. In summer and winter seasons, trajectories show transport mostly from the IGP. Although a dominant contribution from IGP is observed during summer months, we found few trajectories are deriving 
Table 3 Principal component analysis for three sites (BKR, GHy, and RCI) of central east India

\begin{tabular}{|c|c|c|c|c|c|c|c|c|c|}
\hline \multirow[t]{2}{*}{ PAHs } & \multicolumn{3}{|l|}{ BKR } & \multicolumn{3}{|l|}{ GHY } & \multicolumn{3}{|l|}{ RCI } \\
\hline & PC1 & $\mathrm{PC} 2$ & PC3 & PC1 & PC2 & PC3 & PC1 & PC2 & PC3 \\
\hline Nap & 0.23 & 0.17 & 0.20 & 0.22 & 0.24 & -0.11 & 0.16 & 0.41 & 0.12 \\
\hline Acy & 0.21 & 0.00 & 0.44 & 0.16 & 0.31 & 0.39 & 0.14 & 0.67 & 0.22 \\
\hline Ace & 0.28 & 0.15 & 0.18 & 0.21 & 0.04 & 0.36 & 0.19 & 0.09 & -0.43 \\
\hline Flu & 0.28 & -0.23 & 0.33 & 0.24 & 0.23 & 0.06 & 0.23 & 0.24 & -0.32 \\
\hline Phe & 0.24 & 0.23 & -0.46 & 0.28 & -0.16 & 0.05 & 0.33 & -0.02 & 0.09 \\
\hline Ant & 0.30 & -0.28 & -0.25 & 0.33 & -0.43 & -0.14 & 0.34 & -0.25 & 0.14 \\
\hline Flua & 0.25 & 0.06 & -0.10 & 0.26 & 0.14 & 0.08 & 0.30 & -0.06 & 0.24 \\
\hline Pyr & 0.26 & 0.18 & -0.29 & 0.22 & -0.15 & 0.06 & 0.20 & -0.09 & 0.08 \\
\hline $\mathrm{BaA}$ & 0.31 & 0.12 & 0.40 & 0.26 & 0.01 & 0.34 & 0.29 & -0.08 & -0.17 \\
\hline Chr & 0.26 & -0.11 & -0.01 & 0.25 & -0.09 & -0.15 & 0.26 & 0.10 & -0.06 \\
\hline $\mathrm{BbF}$ & 0.29 & -0.22 & -0.19 & 0.33 & -0.08 & 0.27 & 0.31 & 0.02 & -0.54 \\
\hline $\mathrm{BkF}$ & 0.28 & -0.27 & -0.19 & 0.32 & -0.21 & -0.38 & 0.32 & 0.15 & 0.19 \\
\hline $\mathrm{BaP}$ & 0.23 & -0.04 & 0.13 & 0.25 & 0.10 & -0.01 & 0.24 & -0.27 & 0.12 \\
\hline DBahA & 0.14 & 0.30 & 0.02 & 0.12 & 0.42 & -0.03 & 0.15 & 0.02 & 0.41 \\
\hline B(ghi)P & 0.13 & 0.68 & -0.07 & 0.17 & 0.53 & -0.51 & 0.18 & -0.11 & 0.06 \\
\hline $\mathrm{IcP}$ & 0.22 & -0.16 & -0.10 & 0.26 & -0.12 & -0.24 & 0.22 & -0.35 & 0.05 \\
\hline Variance $(\%)$ & 92.95 & 2.66 & 2.34 & 93.56 & 2.82 & 1.13 & 92.71 & 3.61 & 1.67 \\
\hline
\end{tabular}
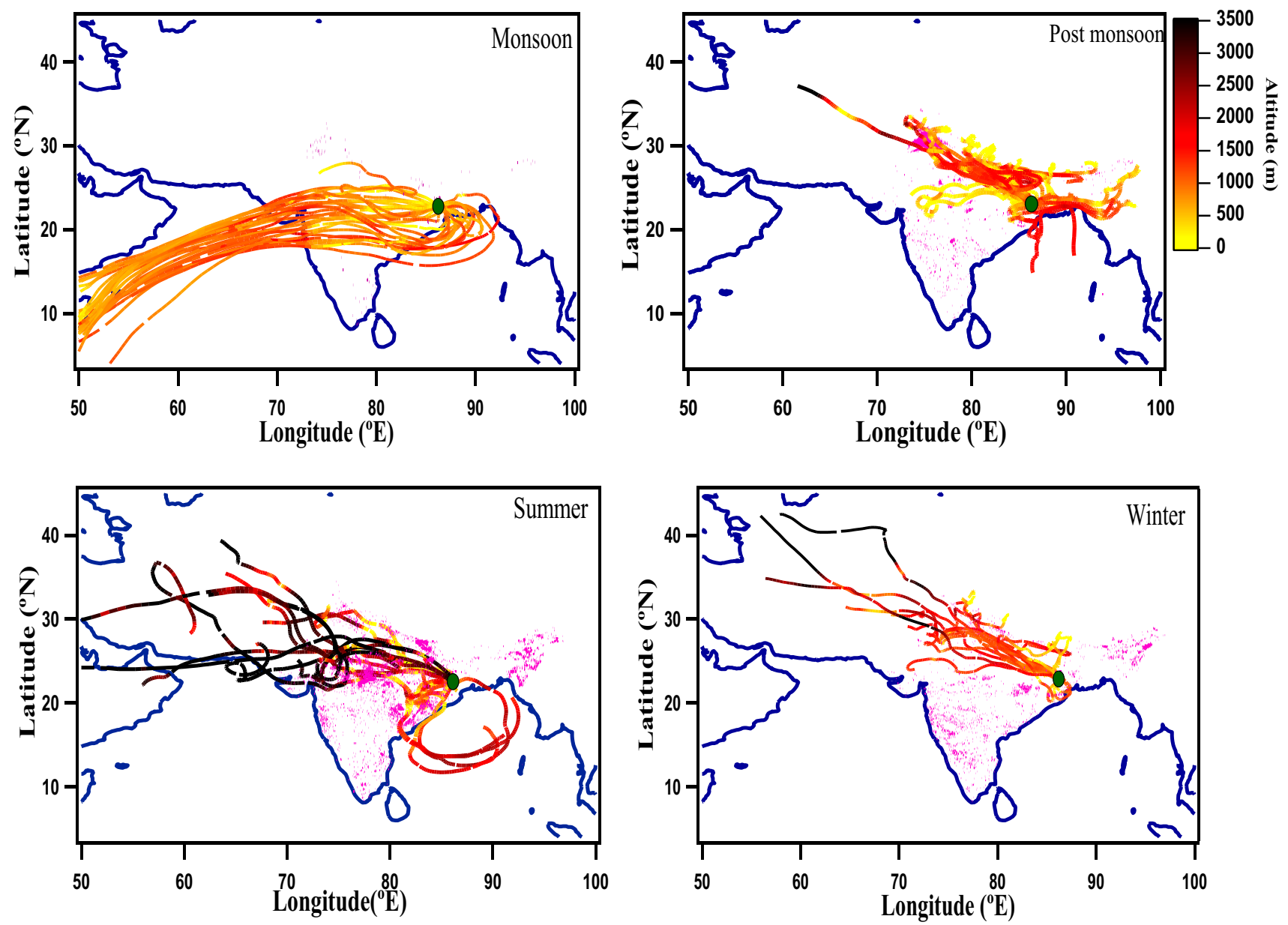

Fig. 6 The 7-day backward trajectories at $500 \mathrm{~m}$ above the earth surface over central east India (latitude $22.8046^{\circ} \mathrm{N}$ and longitude $86.2029^{\circ} \mathrm{E}$ ). The pink dots represent the fire count data 


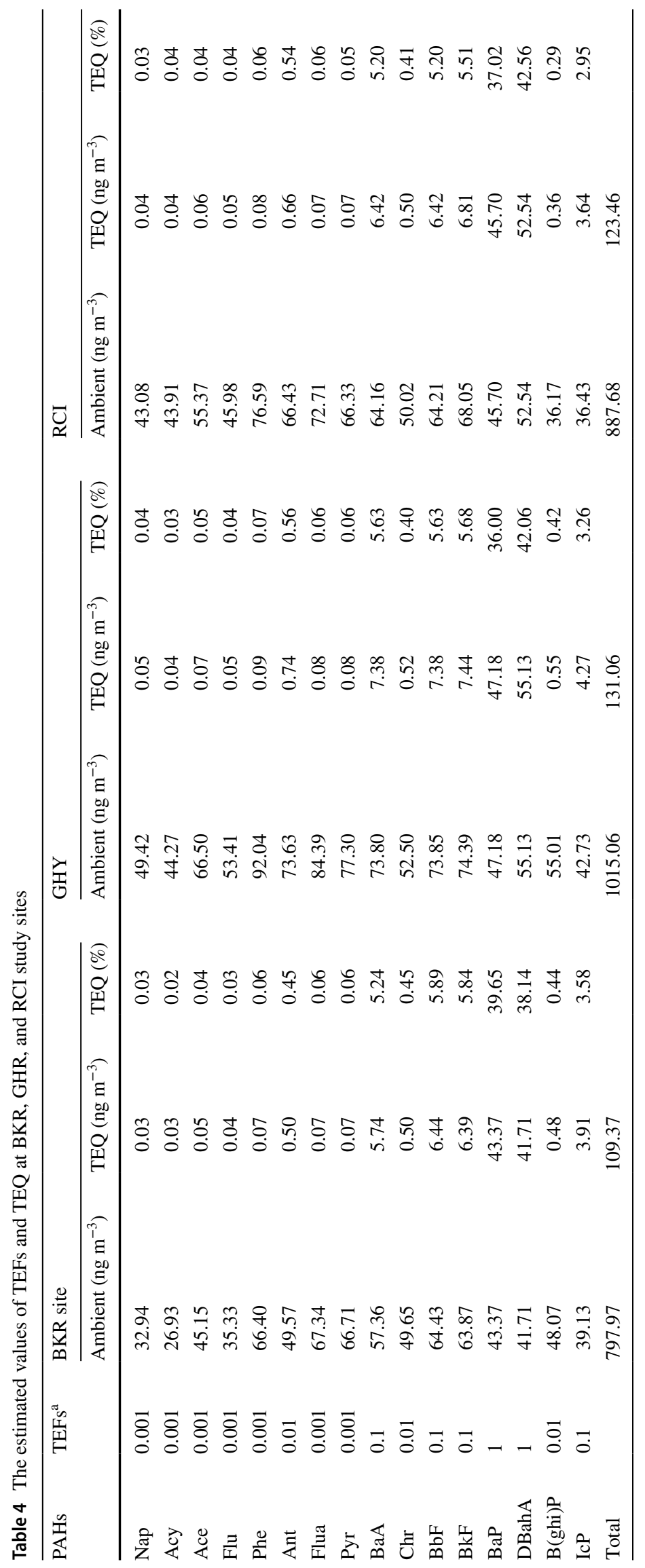


Table 5 Health risk assessment due to PAH exposure to children and adults over the study area

\begin{tabular}{|c|c|c|c|c|}
\hline $\begin{array}{l}\text { Exposure } \\
\text { param- } \\
\text { eter }\end{array}$ & Unit & & Child & Adult \\
\hline $\mathrm{IR}^{\mathrm{a}}$ & $\mathrm{m}^{3}$ day $^{-1}$ & & 10 & 20 \\
\hline $\mathrm{EF}^{\mathrm{b}}$ & days year ${ }^{-1}$ & & 365 & 365 \\
\hline $\mathrm{ED}^{\mathrm{c}}$ & years & & 6 & 24 \\
\hline $\mathrm{BW}^{\mathrm{d}}$ & $\mathrm{kg}$ & & 18 & 60 \\
\hline $\mathrm{AT}^{\mathrm{e}}$ & years & & 70 & 70 \\
\hline \multirow[t]{2}{*}{ Site } & $\begin{array}{l}\text { LADD (mg } \\
\left.\mathrm{kg}^{-1} \mathrm{day}^{-1}\right)\end{array}$ & ILCR & & \\
\hline & Child & Adult & Child & Adult \\
\hline BKR & $5.90 \times 10^{-6}$ & $14.16 \times 10^{-6}$ & $2.27 \times 10^{-5}$ & $5.4 \times 10^{-5}$ \\
\hline GHY & $7.07 \times 10^{-6}$ & $60.97 \times 10^{-6}$ & $2.72 \times 10^{-5}$ & $23.47 \times 10^{-5}$ \\
\hline RCI & $6.66 \times 10^{-6}$ & $15.99 \times 10^{-6}$ & $2.56 \times 10^{-5}$ & $6.15 \times 10^{-5}$ \\
\hline
\end{tabular}

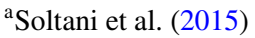

${ }^{\mathrm{b}}$ Kumar et al. (2013)

${ }^{\mathrm{c}}$ USEPA (2011)

${ }^{\mathrm{d}}$ ICMR (2009)

${ }^{\mathrm{e}}$ Ferreira-Baptista and De-Miguel (2005)

from the Bay of Bengal region and possibly will be responsible for lowering the PAH abundance owing to insignificant sources in the marine region. Along with back trajectories, we also observed fire counts in the trajectory map. We observed high density of fire counts over the IGP, which further suggests increased local coal and biomass burning, particularly during winter months. The back trajectories were used to analyze the role of emission source impacting at our sampling site. However, in the winter season, we also observe the trajectories from the southwestern part of India as well as Arabian Peninsula, which was evidence of long-range transport of pollutants toward the study region. Back trajectories concluded that the local or regional as well as long-range mass-loaded pollutants also affect the air quality at study site.

\section{Health risk assessment}

The calculated risk assessment TEQ values for all the sites are presented in Table 4. At BKR, GHY, and RCI sites, the total TEQ values were $109.4,131.1$, and $123.5 \mathrm{ng} \mathrm{m}^{-3}$, respectively. The BaP and DBahA contributed the highest carcinogenicity of PAH samples. Among the PAHs, the BaP contributed to 39.6, 36.0 , and $37.1 \%$ of carcinogenicity at BKR, GHY, and RCI sites, respectively, while the DBahA contributed 38.1, 42.1, and $42.6 \%$ carcinogenicity at BKR, GHY, and RCI sites. This confirms that the $\mathrm{DBahA}$ and $\mathrm{BaP}$ were the major contributors in assessing PAH health risk at the study sites.

In the present study, we have also estimated the probabilistic health risk due to airborne particulate-associated PAHs. The health risk assessed by estimating the LADD values for adults and children and the corresponding ILCR values are given in Table 5. The LADD values for carcinogenic PAHs for the child category were estimated to be $\sim 5.90 \times 10^{-6}, 7.07 \times 10^{-6}$, and $6.66 \times 10^{-6} \mathrm{mg} \mathrm{kg}^{-1} \mathrm{day}^{-1}$ at BKR, GHY, and RCI sites, respectively, while for the adult category, these were $14.16 \times 10^{-6}, 60.97 \times 10^{-6}$, and $15.99 \times 10^{-6} \mathrm{mg} \mathrm{kg}^{-1} \mathrm{day}^{-1}$ respectively. Based on LADDs, the total ILCR values associated with the inhalation of airborne-bound PAHs were estimated to be $\sim 2.27 \times 10^{-5}$, $2.72 \times 10^{-5}$, and $2.56 \times 10^{-5}$ for children at BKR, GHY, and RCI sites, respectively, while for the adults, the ILCR values were estimated to be $\sim 5.4 \times 10^{-5}, 23.47 \times 10^{-5}$, and $6.15 \times 10^{-5}$ at BKR, GHY, and RCI, respectively. According to a previous study in this region, the values of LADD for adult and children were $16.43 \times 10^{-6}$ and $3.16 \times 10^{-6} \mathrm{mg} \mathrm{kg}^{-1} \mathrm{day}^{-1}$, at rural site and $22.3 \times 10^{-6}$ and $4.3 \times 10^{-6} \mathrm{mg} \mathrm{kg}^{-1} \mathrm{day}^{-1}$ at urban site, respectively. Total ILCR values were estimated $63.25 \times 10^{-6}$ for adults and $12.16 \times 10^{-6}$ for children at rural site. At urban site, ILCR value was estimated $85.85 \times 10^{-6}$ for adults and $16.85 \times 10^{-6}$ for children (Kumar et al. 2020a, b). Similar study at three sites of Malaysia including Kuala Lumpur, Petaling Jaya, and Bangi reported that the LADD value for lower than the present value for both adults and children. Further, the excess lifetime cancer risk (ELCR) was estimated by sum of ILCR for adult and ILCR value for child overall study site. The ELCR values over BKR, GHY, and RCI site were found $7.67 \times 10^{-5}, 26.19 \times 10^{-5}$, and $8.71 \times 10^{-5}$. The ELCR value was in the range of acceptable limit $10^{-6}-10^{-4}$ given by regulatory agency USEPA (USEPA., 1989). In the previous study of East India, the ELCR value over urban site was calculated $10.27 \times 10^{-7}$ and over rural site was calculated $75.41 \times 10^{-6}$ (Kumar et al. 2020a, b). The present study result showed that the risk level was acceptable over all the BKR, GHY, and RCI study sites.

\section{Conclusion}

We present here PAH composition and concentration associated with $\mathrm{PM}_{2.5}$ collected from three different sites located in central-eastern India during and their season variability. Following are the major outcome of this study:

1. The $\mathrm{PM}_{2.5}$ annual average mass concentrations of $\mathbf{P M}_{2.5}$ were comparable at all three study sites.

2. PAH concentrations show significant seasonality at all sites in the order of monsoon $<$ post-monsoon $<$ summer $<$ winter.

3. The concentrations of $\mathrm{BaP}$ were found 45.70, 47.18, and $43.37 \mathrm{ng} \mathrm{m}^{-3}$ over RCI, GHY, and BKR sites, respectively. $\mathrm{BaP}$ is considered a marker of carcinogens. The 
concentration of $\mathrm{BaP}$ was significantly higher than the NAAQs standard value of $1 \mathrm{ng} \mathrm{m}^{-3}$.

4. The diagnostic ratio and PCA concluded that the major source of $\mathrm{PM}_{2.5}$-associated PAHs was petrogenic, pyrogenic, coal combustion, and vehicular emission which were predominant sources of emission of PAHs.

5. Backward trajectory analyses coupled with fire count maps were used to further identify various sources during different seasons. In summer and winter seasons, back trajectories suggest a significant contribution from the IGP, with partial contribution from the Bay of Bengal during summer months. We also observed contributions from the southwestern part of India and Arabian countries during monsoon period. However, those samples collected during post-monsoon season were found to be impacted by mixed sources with dominant contribution from those derived from the surrounding regions in Eastern India.

6. The health risk due to PAH exposure in central-east India was also assessed based on the ELCR value and found to lie between acceptable limit values. Thus, the risk level was acceptable over all the BKR, GHY, and RCI study sites of the central part of east India.

This study is an important contribution as the data collected from the sites are just before the COVID-19 pandemic. Thus, it will be very useful in assessing the relative role of air pollution vis-à-vis pandemic in impacting the health of people in this region.

Acknowledgements The authors thank the Meteorological Data Explorer (METEX, http://db.cger.nies.go.jp/metex/trajectory.html) and NASA (National Aeronautics and Space Administration) Fire Information for Resource and Management System (FIRMS) for provision of trajectories data and fire count data (https://firms.modaps.eosdis.nasa. gov/download/) used in the publication.

Funding The Science \& Engineering Research Board financially supported the study, Department of Science \& Technology (SERB- DST) Government of India, and Sanction Order No ECR/2016/000504

Data availability All the data used in the present study will be made available upon request.

\section{Declarations}

Conflict of interest The authors declare no competing interests.

\section{References}

Albinet, A., Leoz-Garziandia, E., Budzinski, H. and ViIlenave, E., 2007. Polycyclic aromatic hydrocarbons (PAHs), nitrated PAHs and oxygenated PAHs in ambient air of the Marseilles area (South of France): Concentrations and sources. Sci Total Environ 384:280-292
Allen JQ, Dookeran NM, Smith KA, Sarofim A, Taghizadeh K, Lafleur AL (1996) Measurement of polycyclic aromatic hydrocarbons associated with size-segregated atmospheric aero-sols in Massachusetts. Environ Sci Technol 30:1023-1031

Alves CA, Barbosa C, Rocha S, Calvo A, Nunes T, Cerqueira M, Pio C, Karanasiou A, Querol X (2015) Elements and polycyclic aromatic hydrocarbons in exhaust particles emitted by light-duty vehicles. Environ Sci Pollut Res 22:11526-11542

Ambade B, Kumar A, Sahu LK (2021) Characterization and health risk assessment of particulate bound polycyclic aromatic hydrocarbons (PAHs) in indoor and outdoor atmosphere of Central East India. Environ Sci Pollut Res. https://doi.org/10.1007/ s11356-021-14606-x

Atkinson R, Aschmann SM, Arey J, Zielinska B, Schuetzle D (1989) Gas-phase atmospheric chemistry of 1-nitronaphthalene and 2-nitronaphthalene and 1,4-naphthoquinone. Atmos Environ 23:2679-2690

Atkinson R, Arey J, Zielinska B, Aschmann SM (1990) Kinetics and nitro-products of the gas-phase oh and $\mathrm{NO} 3$ radical-initiated reactions of naphthalene-d8, fluoranthene-d10, and pyrene. Int J Chem Kinet 22:999-1014

Baek SO, Field RA, Goldstone ME, Kirk PW, Lester JN, Perry R (1991a) A review of atmospheric polycyclic aromatic hydrocarbons: sources, fate and behavior. Water, Air, Soil Poll 60:79-300

Baek SO, Goldstone ME, Kirk PWW, Lester JLN, Perry R (1991b) Phase distribution and particle size dependency of polycyclic aromatic hydrocarbons in the urban environment. Chemosphere 22:503-520

Barbas JT, Sigman ME, Dabestani R (1996) Photochemical oxidation of phenanthrene sorbed on silica gel. Environ Sci Technol 30:1776-1780

Cerná, M., Pastorková, A., Vrbíková, V., Smíd, J., Rössner, P., 1999. 422 Mutagenicity monitoring of airborne particulate matter $\left(\mathrm{PM}_{10}\right) 423$ in the Czech Republic. Mutat. Res. Genet. Toxicol. Environ. 424 Mutagen. 444 (2), 373-386

Chen SC, Liao CM (2006) Health risk assessment on human exposed to environmental polycyclic aromatic hydrocarbons pollution sources. Sci Total Environ 366:112-123

Chen YJ, Feng YL, Xiong SC, Fu JM (2011) Polycyclic aromatic hydrocarbons in the atmosphere of Shanghai. China Environ Monit Assess 172:235-247

De La Torre-Roche RJ, Lee W-Y, Campos-Díaz SI (2009) Soil-borne polycyclic aromatic hydrocarbons in El Paso, Texas: analysis of a potential problem in the United States/ Mexico border region. J Hazard Mater 163:946-958

Dimashki M, Lim LH, Harrison RM, Harrad S (2001) Temporal trends, temperature dependence, and relative reactivity of atmospheric polycyclic aromatic hydrocarbons. Environ Sci Technol 35:2264-2267

Environmental Health Criteria (EHC) 229 (2003) Selected nitro- and nitro-oxy-polycyclic aromatic hydrocarbons. WHO Library. http:// whqlibdoc.who.int/ehc/WHO_EHC_229.pdf

Fang GC, Wu YS, Chen JC, Chang CN, Ho TT (2006a) Characteristic of polycyclic aromatic hydrocarbon concentrations and source identification for fine and coarse particulates at Taichung Harbor near Taiwan Strait during 2004-2005. Sci Total Environ 366:729-738

Ferreira-Baptista L, De-Miguel E (2005) Geochemistry and risk assessment of street dust in Luanda: Angola. A Tropical Urban Environment Atmos Environ 39:4501-4512

Froehner S, Maceno M, Scurupa Machado K, Grube M (2011) Health risk assessment of inhabitants exposed to PAHs particulate matter in air. J Environ Sci Health, A Tox Hazard Subst Environ Eng $46: 817-823$ 
Galarneau E (2008) Source specificity and atmospheric processing of airborne PAHs: implications for source apportionment. Atmos Environ 42:8139-8149

Guo H, Lee SC, Ho KF, Wang XM, Zou SC (2003) Particle-associated polycyclic aromatic hydrocarbons in urban air of Hong Kong. Atmos Environ 37:5307-5317

Hafner WD, Carlson DL, Hites RA (2005) Influence of local human population on atmospheric polycyclic aromatic hydrocarbon concentrations. Environ Sci Technol 39:7374-7379

Harvey, R.G., 1997. Polycyclic aromatic hydrocarbons. John Wiley \& Sons, New York. Hassanipour, S., Mokhtari, A.M., Fathalipour, M., Salehiniya, H., 2017. In: Hassanipour, S., Mokhtari, A.M., Fathalipour, M., Salehiniya, H. (Eds.), The incidence of lung cancer in Iran: a systematic review and meta-analysis. 4. pp. 1-7

Helmig D, Harger WP (1994) OH radical-initiated gas-phase reaction products of phenanthrene. The Science of the Total Environment 148:11-21

Hussain K, Rahman M, Prakash A, Hoque RR (2015) Street dust bound PAHs, carbon and heavy metals in Guwahati city seasonality: toxicity and sources. Sustain Cities Soc 19:17-25

ICMR (2009). Nutrient requirements and recommended dietary allowances for Indians. A report of the expert group of the Indian Council of Medical Research Hyderabad, India: National Institute of Nutrition

Kamal A, Cincinelli A, Martellini T, Malik RN (2015) A review of PAH exposure from the combustion of biomass fuel and their less surveyed effect on the blood parameters. Environ Sci Pollut Res Int 22(6):4076-4098

Kaya E, Dumanoglu Y, Kara M, Altiok H, Bayram A, Elbir T, Odabasi M (2012) Spatial and temporal variation and air - soil exchange of atmospheric PAHs and PCBs in an industrial region. Atmos Pollut Res 3:435-449

Kong S, Lu B, Ji Y, Bai Z, Xu Y, Liu Y, Jiang H (2012) Distribution and sources of polycyclic aromatic hydrocarbons in size-differentiated re-suspended dust on building surfaces in an oilfield city. China Atmos Environ 55:7-16

Kumar, A., Ambade, B., Sankar, T.K., Sethi, S.S., Kurwadkar, S., 2020. Source identification and health risk assessment of atmospheric $\mathrm{PM}_{2.5}$-bound polycyclic aromatic hydrocarbons in Jamshedpur, India. Sustain. Cities Soc. 52, 101801

Kumar A, Sankar TK, Sethi SS, Ambade B (2020b) Characteristics, toxicity, source identification and seasonal variation of atmospheric polycyclic aromatic hydrocarbons over East India. Environ Sci Pollut Res Int 27(1):678-690

Kumar M, Furumai H, Kurisu F, Kasuga I (2013) Tracing source and distribution of heavy metals in road dust: soil and soak away sediment through speciation and isotopic fingerprinting. Geoderma 211-212:8-17

Larsen RK, Baker JE (2003) Source apportionment of polycyclic aromatic hydrocarbons in the urban atmosphere: a comparison of three methods. Environ Sci Technol 37:1873-1881

Lima ALC, Farrington JW, Reddy CM (2005) Combustion-derived polycyclic aromatic hydrocarbons in the environment-a review. Environ Forensic 6:109-131

Liu Y, Zhu L, Shen X (2001) Polycyclic aromatic hydrocarbons (PAHs) in indoor and outdoor air of Hangzhou. China Environ Sci Technol 35:840-844

Luo X-J, Chen S-J, Mai B-X, Yang Q-S, Sheng G-Y, Fu J-M (2006) Polycyclic aromatic hydrocarbons in suspended particulate matter and sediments from the Pearl River Estuary and adjacent coastal areas. China Environ Pollut 139(1):9-20

Miller L, Lemke LD, Xu X, Molaroni SM, You H, Wheeler AJ, Booza J, GrgicakMannion A, Krajenta R, Graniero P, Krouse H, Lamerato L, Raymond D, Reiners J, Weglicki L (2010) Intraurban correlation and spatial variability of air toxics across an international airshed in Detroit, Michigan (USA). Atmos Environ 44:1162-1174

Motelay-Massei A, Ollivon D, Garban B, Chevreuil M (2003) Polycyclic aromatic hydrocarbons in bulk deposition at a suburban site: assessment by principal component analysis of the influence of meteorological parameters. Atmos Environ 37:3135-3146

NAAQS (National Ambient Air Quality Standards) (2009) Ministry of forest and environment. Government of India, New Delhi

Neilson, O., 2010. PAHs and related compounds - chemistry: the handbook of environmental chemistry (Vol. 3. Part I: anthropogenic compounds). New York: Springer

Nisbet ICT, Lagoy PK (1992) Toxic equivalency factors (TEFs) for polycyclic aromatic hydrocarbons (PAHs). Regul Toxicol Pharmacol 16(3):290-300

Novakov T, Ramanathan V, Hansen JE, Kirchstetter TW, Sato M, Sinton JE, Sathaye JA (2003) Large historical changes of fossil-fuel black carbon aerosols. Geophys Res Letts 30:1324. https://doi.org/ 10.1029/2002GL016345

Obiri S, Cobbina SJ, Armah FA, Naangmenyele Z (2011) Quantification and characterization of vehicle-based polycyclic aromatic hydrocarbons (PAHs) in street dust from the Tamale metropolis. Ghana Environ Sci Pollut Res 18:1166-1173

Panther BC, Hooper MA, Tapper NJ (1999) A comparison of air particulate matter and associated polycyclic aromatic hydrocarbons in some tropical and temperate urban environments. Atmos Environ 33:4087-4099

Park SS, Kim YJ, Kang CH (2002) Atmospheric polycyclic aromatic hydrocarbons in Seoul. Korea Atmos Environ 36:2917-2924

Praveena K, Kunhkrishnan PK (2004) Temporal variations of ventilation coefficient at a tropical Indian station using UHF wind profiler. Curr Sci 86:447-450

Peng C, Chen WP, Liao XL, Wang ME, Ouyang ZY, Jiao WT, Bai Y (2011) Polycyclic aromatic hydrocarbons in urban soils of Beijing: status, sources, distribution and potential risk. Environ Pollut 159:802-808

Pies C, Hoffmann B, Petrowsky J, Yang Y, Ternes TA, Hofmann T (2008) Characterization and source identification of polycyclic aromatic hydrocarbons (PAHs) in river bank soils. Chemosphere 72:1594-1601

Rajput N, Lakhani A (2009) Measurements of polycyclic aromatic hydrocarbons at an industrial site in India. Environ Monit Assess 150:273-284

Ravindra K, Sokhi R, Van Grieken R (2008) Atmospheric polycyclic aromatic hydrocarbons: source attribution, emission factors and regulation. Atmos Environ 42:2895-2921

Saranath D, Khanna A (2014) Current status of cancer burden: global and Indian scenario. Biomed Res J 1(1):1-5

Sahu LK, Saxena P (2015) High time and mass resolved PTR-TOF-MS measurements of VOCs at an urban site of India during winter: role of anthropogenic, biomass burning, biogenic and photochemical sources. Atmos Res 164-165:84-94

Sahu LK, Yadav R, Pal D (2016) Source identification of VOCs at an urban site of western India: effect of marathon events and anthropogenic emissions. J Geophys Res Atmos 121:2416-2433

Sasaki J, Aschmann SM, Kwok ESC, Atkinson R, Arey J (1997) Products of the GasPhase $\mathrm{OH}$ and $\mathrm{NO} 3$ radical-initiated reactions of naphthalene. Environ Sci Technol 31:3173-3179

Sharma H, Jain VK, Khan ZH (2007) Characterization and source identification of polycyclic aromatic hydrocarbon (PAH) in the urban environment of Delhi. Chemosphere 66:302-310

Shen M, Liu G, Yin H, Zhou L (2020) Distribution, sources and health risk of PAHs in urban air-conditioning dust from Hefei, East China. Ecotoxicol Environ Safety 194:110442 (ISSN 0147 6513)

Sheu HL, Lee WJ, Lin SJ, Fang GC, Chang HC, You WC (1997) Particle-bound PAH content in ambient air. Environ Pollut 96:369-382 
Singla V, Pachauri T, Satsangi A, Kumari KM, Lakhani A (2012) Characterization and mutagenicity assessment of $\mathrm{PM}_{2.5}$ and $\mathrm{PM}_{10} \mathrm{PAH}$ at Agra India. Polycycl Aromat Compd 32(2):199-220

Slezakova K, Castro D, Delerue-Matos C, Alvim-Ferraz MC, Morais S, Pereira MC (2011) Air pollution from traffic emissions in Oporto, Portugal: health and environmental implications. Microchem J 99:51-59

Soltani N, Keshavarzi B, Moore F, Tavakol T, Lahijanzadeh AR, Jaafarzadeh N, Kermani M (2015) Ecological and human health hazards of heavy metals and polycyclic aromatic hydrocarbons (PAHs) in street dust of Isfahan metropolis. Iran Sci Total Environ 505:712-723

Streets DG, Yarber KF, Woo JH, Carmichael GR (2003) Biomass burning in Asia: annual and seasonal estimates and atmospheric emissions. Global Biogeochem Cycles 17(4):1099. https://doi.org/10. 1029/2003gb002040

Tobiszewski M, Namieśnik J (2012) PAH diagnostic ratios for the identification of pollution emission sources. Environ Pollut 162:110-119

United States Environmental Protection Agency (USEPA) (1986) Guidelines for carcinogen risk assessment. Federal Register, 51, 185. US Government Printing Office, Washington, DC

USEPA., 2011. Exposure factors handbook edition. EPA/600/R09/052F. Washington, D.C: National Center for Environmental Assessment, Office of Research and Development, U.S. Environmental Protection Agency 20460.

Venkataraman C, Lyons JM, Friedlander SK (1994) Size distributions of polycyclic aromatic hydrocarbons and elemental carbon. 1. Sampling, measurement methods, and source characterization. Environ Sci Technol 28:555-562

Vestreng, V., \& Klein, H., 2002. Emission data reported to UNECE/ EMEP: quality assurance and trend analysis and presentation of WebDab. MSC-W Status Report (2002). EMEP-MSC-W Note 1/2002. Oslo, Norway: Meteorological Synthesizing Centre-West.

Wang F, Lin T, Li Y, Ji T, Ma C, Guo Z (2014a) Sources of polycyclic aromatic hydrocarbons in $\mathrm{PM}_{2.5}$ over the East China Sea, a downwind domain of East Asian continental out flow. Atmos Environ 92:484-492
Wang J, Geng NB, Xu YF, Zhang WD, Tang XY, Zhang RQ (2014b) PAHs in $\mathrm{PM}_{2.5}$ in Zhengzhou: concentration, carcinogenic risk analysis, and source apportionment. Environ Monit Assess 186:7461-7473

Wang W, Huang M-J, Kang Y, Wang H-S, Leung AO, Cheung KC, Wong MH (2011) Polycyclic aromatic hydrocarbons (PAHs) in urban surface dust of Guangzhou, China: status, sources and human health risk assessment. Sci Total Environ 409:4519-4527

Wild SR, Jones KC (1995) Polynuclear aromatic hydrocarbons in the United Kingdom environment: a preliminary source inventory and budget. Environ Pollut 88:91-108

Yang X, Okada Y, Tang N, Matsunaga S, Tamura K, Lin J, Kameda T, Toriba A, Hayakawa K (2007) Long-range transport of polycyclic aromatic hydrocarbons from China to Japan. Atmos Environ 41:2710-2718

Yebra-Pimentel I, Fernández-González R, Martínez-Carballo E, SimalGándara J (2015) A critical review about the health risk assessment of PAHs and their metabolites in foods. Crit Rev Food Sci Nutr 55(10):1383-1405

Yu Y, Guo H, Liu Y, Huang K, Wang Z, Zhan X (2008) Mixed uncertainty analysis of polycyclic aromatic hydrocarbon inhalation and risk assessment in ambient air of Beijing. J Environ Sci 20:505-512

Yunker M, MacDonald R, Vingarzan R, Mitchell R, Goyette D, Sylvestre $S$ (2002) PAHs in the Fraser River basin: a critical appraisal of PAH ratios as indicators of PAH source and composition. Org Geochem 33:489-515

Zhang X, Tao S, Liu W, Yang Y, Zuo Q, Liu S (2005) Source diagnostics of polycyclic aromatic hydrocarbons based on species ratios: a multimedia approach. Environ Sci Technol 39:9109-9114

Zonguldak Governorship 2007. Environment and Forestry Management, Environment Situation Report, Zonguldak

Publisher's note Springer Nature remains neutral with regard to jurisdictional claims in published maps and institutional affiliations. 